\title{
PENGARUH EXPERIENTIAL MARKETING TERHADAP KEPUTUSAN PEMBELIAN KONSUMEN GENERASI MILLENIAL PADA PLATFORM E-COMMERCE
}

\author{
Rina Nur Chasanah ${ }^{1}$, Oktafalia Marisa Muzammil ${ }^{2}$, Janny Rowena ${ }^{3}$ \\ 1.Program Studi Manajemen Universitas Bunda Mulia.Jakarta. rchasanah@bundamulia.ac.id \\ ${ }^{2}$ Program Studi Manajemen Universitas Bunda Mulia.Jakarta. omuzammil@bundamulia.ac.id \\ ${ }^{3}$ Program Studi Manajemen Universitas Bunda Mulia. Jakarta. jrowenal@bundamulia.ac.id
}

\begin{abstract}
ABSTRAK
Berdasarkan data yang dimiliki oleh Asosiasi Penyelenggara Jasa Internet Indonesia (APJII) adalah sekitar 143 juta jiwa telah terhubung dengan jaringan internet sepanjang tahun 2017 yang lalu. Mayoritas pengguna internet sebanyak 72,41\% kalangan masyarakat urban dengan pemanfaatan antara lain untuk berkomunikasi, membeli barang, memesan transportasi, hingga berbisnis dan berkarya.Sebanyak 49,52\% pengguna internet di Tanah Air adalah mereka yang berusia 19 hingga 34 tahun, yang merupakan generasi $\mathrm{Y}$ atau generasi millennial. Sejalan dengan berkembangnya pengguna internet di Indonesia maka perilaku konsumen dalam melakukan pembelian mengalami perubahan (shifting), dari yang dulu melakukanpembelian melalui toko fisik maka saat ini berbelanja secara daring menjadi pilihan bagi masyarakat saat ini. Hasil survei terbaru dari lembaga riset Snapcart di Januari 2018 mengungkapkan bahwa generasi millenial menjadi pembelanja terbanyak di bidang e-commerceyakni sebanyak $50 \%$.

Subjek dari penelitian peneliti adalah 100 konsumen generasi millenial yang melakukan keputusan pembelian di platform ecommerce Blibli.com. Objek penelitiannya adalah tentang experiential marketing yang terdiri dari 5 variabel diantaranya adalah sense marketing, think marketing, act marketing, feel marketing dan relate marketing terhadap keputusan pembelian di platform ecommerce Blibli.com. Dalam penelitian ini peneliti akan menggunakan kuesioner. Metode analisis yang peneliti gunakan adalah regresi berganda. Tujuan penelitian adalah untuk melihat apakah terdapat pengaruh yang signifikan experiential marketing terhadap keputusan pembelian konsumen generasi millennial pada platform e-commerce. Hasil penelitian mengungkap bahwa variabel feel, think dan act berpengaruh terhadap keputusan pembeliangenerasi millennial pada platform e-commerce. Sedangkan variabel sense dan relate tidak berpengaruh terhadap keputusan pembeliangenerasi millennial pada platform e-commerce dengan tingkat keyakinan $95 \%$.
\end{abstract}

Kata kunci : experiential marketing, keputusan pembelian 


\title{
National Conference of Creative Industry: \\ Sustainable Tourism Industry for Economic Development
}

Universitas Bunda Mulia, Jakarta, 5-6 September 2018

E- ISSN No: 2622-7436

\begin{abstract}
Based on the data held by the Indonesian Internet Service Providers Association (APJII), around 143 million people have been connected to the internet network throughout the past 2017. The majority of internet users as many as $72.41 \%$ of the urban community with the use of, among others, to communicate, buy goods, order transportation, to do business and work. As many as $49.52 \%$ of internet users in the country are those aged 19 to 34 years, who are generation $Y$ or millennial generation. In line with the development of internet users in Indonesia, the behavior of consumers in making purchases has changed (shifting), from those who previously made purchases through physical stores, now shopping online is an option for today's society. The results of a recent survey from the Snapcart research institute in January 2018 revealed that the millennial generation has become the largest shopper in the e-commerce sector, which is as much as $50 \%$.

The subjects of the research study were 100 millennials consumers who made purchasing decisions on Blibli.com e-commerce platform. The object of his research is about experiential marketing which consists of 5 variables including marketing sense, think marketing, marketing act, marketing feel and marketing relationship to purchasing decisions on Blibli.com e-commerce platform. In this study researchers will use a questionnaire. The method of analysis that researchers use is multiple regression. The aim of the research is to see whether there is a significant influence of experiential marketing on millennial consumer purchasing decisions on e-commerce platforms. The results of the study revealed that the variable feel, think and act influence the purchasing decisions of millennials on e-commerce platforms. While sense and relate variables do not affect the millennial generation purchasing decisions on e-commerce platforms with a 95\% confidence level.
\end{abstract}

Keywords: experiential marketing, purchasing decisions

\section{PENDAHULUAN}

Perkembangan penggunaan internet di Indonesia telah mencapai setengah dari jumlah populasi penduduk di Indonesia. Data yang dimiliki oleh Asosiasi Penyelenggara Jasa Internet Indonesia (APJII) adalah sekitar 143 juta jiwa telah terhubung dengan jaringan internet sepanjang tahun 2017 yang lalu. Mayoritas pengguna internet sebanyak $72,41 \%$ kalangan masyarakat urban dengan pemanfaatan antara lain untuk berkomunikasi, membeli barang, memesan transportasi, hingga berbisnis dan berkarya.

Internet tak bisa dipisahkan dari kehidupan sehari-hari anak muda saat ini Sebanyak 49,52\% pengguna internet di Tanah Air adalah mereka yang berusia 19 hingga 34 tahun. Kelompok ini mengabsahkan profesi-profesi baru di ranah maya, semisal Selebgram (selebritas Instagram) dan YouTuber (pembuat konten YouTube). Menjamurnya perusahaan rintisan digital atau startup pun sedikit banyak digerakkan oleh kelompok usia ini, baik mereka sebagai pendiri atau konsumen. Di posisi kedua, 


\section{National Conference of Creative Industry: \\ Sustainable Tourism Industry for Economic Development}

Universitas Bunda Mulia, Jakarta, 5-6 September 2018

E- ISSN No: 2622-7436

sebanyak 29,55 persen pengguna internet Indonesia berusia 35 hingga 54 tahun. Kelompok ini berada pada usia produktif dan mudah beradaptasi dengan perubahan. Remaja usia 13 hingga 18 tahun menempati posisi ketiga dengan porsi 16,68\%. Terakhir, orang tua di atas 54 tahun hanya 4,24\% yang memanfaatkan internet.

Sejalan dengan berkembangnya pengguna internet di Indonesia maka perilaku konsumen dalam melakukan pembelian mengalami perubahan (shifting), jika beberapa waktu lalu masyarakat masih melakukan pembelian melalui toko fisik maka saat ini berbelanja secara daring menjadi pilihan yang menjadi favorit bagi masyarakat saat ini. Perubahan ini terlihat lewat aktivitas yang meningkat di platform e-commerce. Hasil survei terbaru lembaga riset Snapcart di Januari 2018 mengungkapkan bahwa generasi millenial menjadi pembelanja terbanyak di bidang e-commerce yakni sebanyak $50 \%$ (25-34 tahun). Karakteristik generasi millenial yang lekat dengan teknologi kemudian dimanfaatkan oleh perusahaan-perusahaan e-commerce untuk hal promosi. Terbukti hampir semua sumber informasi tentang e-commerce berasal dari media digital.

Salah satu platform e-commerce yang menarik perhatian pengguna internet adalah Blibli.com. Platform ini mulai hadir di Indonesia sejak 2011 dan terus berkembang hingga saat ini. Blibli.com terus memperhatikan fenomena shiftingterutama perubahan perilaku konsumen dalam melaukan keputusan pembelian pada generasi millenial tersebut, salah satu bukti nyatanya adalah keterlibatan blibli.com The Bigstart Indonesia. Hal inilah yang menarik perhatian penulis untuk meneliti lebih dalam mengenai experential marketing di salah satu platform $e$-commerce di Indonesia

\section{TINJAUAN PUSTAKA}

\section{Experiential Marketing}

Experiential marketing merupakan strategi pemasaran yang memberikan pengalaman emosional yang unik, positif dan mengesankan kepada customer. Pengalaman itu adalah berupa emotional benefit yang ditawarkan lembaga sesuai dengan kebutuhan konsumen.

Dapat dikatakan bahwa pengertian experiential marketing adalah suatu aktivitas untuk melakukan antisipasi, pengelolaan dan pencapaian kepuasan konsumen melalui proses pertukaran yang merupakan peristiwa-peristiwa pribadi yang terjadi sebagai tanggapan atau beberapa stimulus.

\section{Elemen-Elemen Experiential Marketing}

Elemen-Elemen Experiential Marketing (Schmitt, 2009) terdiri dari:

1. Sense, 'Sense' berkaitan dengan gaya (styles) dan simbol-simbol verbal dan visual yang mampu menciptakan keutuhan sebuah kesan.

2. Feel, Perasaan di sini sangatlah berbeda dengan kesan sensorik karena hal ini berkaitan dengan suasana hati dan emosi jiwa seseorang. Ini bukan sekedar menyangkut keindahan, tetapi suasana hati dan emosi jiwa yang mampu membangkitkan kebahagiaan atau bahkan kesedihan.

3. Think, Dengan berpikir (think) dapat merangsang kemampuan intelektual dan kreativitas seseorang. 


\section{National Conference of Creative Industry: \\ Sustainable Tourism Industry for Economic Development}

Universitas Bunda Mulia, Jakarta, 5-6 September 2018

E- ISSN No: 2622-7436

4. Act berkaitan dengan perilaku yang nyata dan gaya hidup seseorang. Hal ini berhubungan dengan bagaimana membuat orang berbuat sesuatu dan mengekspresikan gaya hidupnya.

5. Relate berkaitan dengan budaya seseorang dan kelompok referensinya yang dapat menciptakan identitas sosial.

\section{Karakteristik Experiential Marketing}

Menurut Schmitt dalam Endang Sulistya Rini (2009) memiliki empat karakteristik yaitu:

1.Fokus pada pengalaman konsumen

Suatu pengalaman terjadi sebagai pertemuan, menjalani atau melewati situasi tertentu yang memberikan nilai-nilai fungsional.

2.Menguji situasi konsumen

Berdasarkan pengalaman yang telah ada konsumen tidak hanya menginginkan suatu produk dilihat dari keseluruhan situasi pada saat mengkonsumsi produk tersebut tetapi juga dari pengalaman yang didapatkan pada saat mengkonsumsi produk tersebut.

3.Mengenali aspek rasional dan emosional sebagai pemicu konsumsi

Dalam experiential marketing konsumen bukan hanya dilihat dari sisi rasional saja melainkan juga dari sisi emosionalnya.

4.Metode dan perangkat bersifat elektik

Metode dan perangkat untuk mengukur pengalaman seseorang lebih bersifat elektik. Maksudnya adalah lebih bergantung kepada objek yang akan diukur atau lebih mengacu pada setiap situasi yang terjadi daripada menggunakan suatu standar yang sama.

\section{Keputusan Pembelian}

Keputusan Pembelian menurut Kotler dan Keller (2012 : 192), adalah tahap dimana konsumen membentuk kecenderungan dalam memilih antara beberapa brand dan juga dapat membentuk niat untuk membeli brand yang paling disukai. Dalam melaksanakan suatu intensitas pembelian, konsumen dapat membuat hingga lima pilihan yaitu brand, penjual, jumlah, waktu dan cara pembayaran.

Engel, Blackwell dan Kollat mengungkapkan ada lima tahap pengambilan keputusan saat seseorang membeli sesuatu.

\section{Tahap Pertama: Pengenalan Masalah/Kebutuhan}

Mengenali masalah dan kebutuhan serta mengidentifikasi produk atau tipe produk yang diperlukan. Ini adalah tahap pertama dan terpenting dalam pengambilan keputusan konsumen. Pembelian tidak akan terjadi tanpa pengenalan kebutuhan.

\section{Tahap Kedua: Pencarian Informasi}

Setelah mengenali masalah atau kebutuhannya, konsumen akan mencari informasi produk yang akan memenuhi kebutuhannya. Tujuannya adalah menemukan solusi terbaik bagi masalahnya. Konsumen akan mencari informasi entah melalui media offline dan online. Dalam penelitian ini akan diteliti mengenai perubahan perilaku konsumen dalam pemanfaatan teknologi internet

\section{Tahap Ketiga: Evaluasi Alternatif}

Konsumen mengevaluasi berbagai alternatif produk. Memilih produk yang paling cocok dan disukai. Proses evaluasi ini tidak selalu logis, bisa saja tidak logis, emosional 
atau dipengaruhi oleh pendapat-pendapat di luar dirinya (testimoni, rekomendasi ahli, dsb)

\section{Tahap Keempat: Keputusan Pembelian}

Setelah mengevaluasi beberapa opsi, konsumen akhirnya membeli salah satu produk yang paling cocok baginya. Philip Kotler mengatakan bahwa keputusan akhir ini bisa saja 'terganggu' oleh umpan balik negatif dari konsumen lain.

\section{Tahap Kelima: Perilaku Pasca Pembelian}

Setelah membeli, konsumen akan membandingkan produk yang dibelinya dengan ekspektasi sebelumnya. Bisa saja ia merasa puas atau sebaliknya, tidak puas. Seringkali terjadi juga konsumen mengalami semacam disonansi kognitif. Jika konsumen puas, mereka cenderung akan membeli ulang, bahkan merekomendasikan produk tersebut kepada lingkungannya. Sementara jika tidak puas, dia akan menyebarluaskan umpan balik negatif kepada teman-temannya. Entah melalui sosial media atau melalui word of mouth .

Memahami lima tahap keputusan pembelian ini membantu kita mengetahui apa yag perlu dilakukan agar konsumen membeli produk kita. Memahami tahap-tahap ini juga membantu kita menentukan tahap-tahap dalam mempromosikan produk kita yaitu:

1. Menyadarkan konsumen akan masalah/kebutuhannya.

2. Menyediakan informasi/pengetahuan terkait produk terkait kita.

3. Memberikan alasan mengapa produk tersebut lebih baik daripada produk pesaing.

4. Mengajak konsumen membeli produk tersebut.

\section{Paradigma Penelitian}

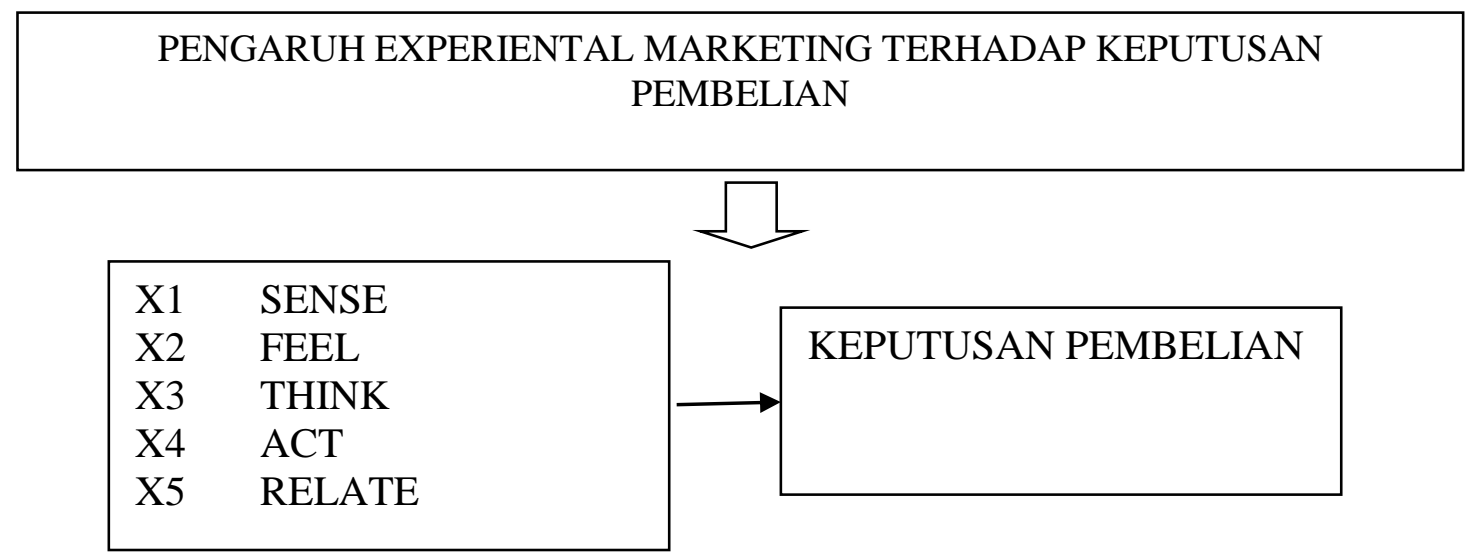

Berdasarkan pendapat Sugiyono (2009) objek penelitian merupakan suatu atribut atau sifat atau nilai dari orang, objek atau kegiatan yang mempunyai variasi tertentu yang ditetapkan oleh peneliti untuk di pelajari dan kemudian ditarik kesimpulannya.

Objek penelitian dalam penelitian ini adalah tentang experiential marketing yang terdiri dari 5 variabel diantaranya adalah sense marketing, think marketing, act marketing, feel marketing dan relate marketing terhadap keputusan pembelian generasi millenial pada platform e-commerce 


\section{National Conference of Creative Industry: \\ Sustainable Tourism Industry for Economic Development}

Universitas Bunda Mulia, Jakarta, 5-6 September 2018

E- ISSN No: 2622-7436

Subjek Penelitian

Berdasarkan pendapat Arikunto (2010) subjek penelitian merupakan sesuatu yang sangat penting kedudukannya di dalam penelitian, subjek penelitian harus ditata sebelum peneliti siap untuk mengumpulkan data. Subjek penelitian dapat berupa benda, hal, atau orang. subjek penelitian peneliti adalah 100 konsumen generasi millenial yang melakukan keputusan pembelian di platform ecommerce Blibli.com

Teknik Pengumpulan Data

Dalam penelitian ini peneliti akan menggunakan kuisioner, menurut Sugiyono (2009) kuesioner merupakan teknik pengumpulan data yang dilakukan dengan cara memberi seperangkat pertanyaan atau pernyataan tertulis kepada responden untuk dijawabnya.

Populasi

Populasi yang peneliti ambil adalah konsumen generasi millenial yang melakukan keputusan pembelian di platform ecommerce Blibli.com

Sampel

Penelitian ini mempunyai lima variabel independen (feel, think, act, sense, relate) ditambah dengan satu variabel dependen (loyalitas) maka peneliti akan mengambil 100 sampelkonsumen generasi millenial yang melakukan keputusan pembelian di platform ecommerce Blibli.com.

Metode Analisis

Metode analisis yang peneliti gunakan adalah regresi berganda, menurut Sugiyono (2009) analisis regresi ganda digunakan oleh peneliti, bila peneliti bermaksud meramalkan bagaimana keadaan (naik turunnya) variabel dependen, bila dua atau lebih variabel independen sebagai faktor predictor dimanipulasi (dinaik turunkan nilainya). Dalam hal pengolahan data, peneliti menggunakan metode skala interval.

Metode Pengujian Validitas dan Reliabilitas

Validitas

Menurut Ghozali (2006) Uji validitas digunakan untuk mengukur sah atau tidaknya dan valid tidaknya suatu kuisioner. Valid atau tidaknya itu ditentukan jika $r$ hitung lebih besar daripada $\mathrm{r}$ tabel

Reliabilitas

Menurut Sugiyono (2010) Dengan menggunakan instrumen yang valid dan reliabel dalam pengumpulan data, maka diharapkan hasil penelitian akan menjadi valid dan reliabel. Jadi instrumen yang valid dan reliabel merupakan syarat mutlak untuk mendapatkan hasil penelitian yang valid dan reliabel. Suatu variabel dapat dikatakan reliabel jika memberikan nilai Cronbach's Alpha $>0,60$. Uji reliabilitas menggunakan uji Cronbach's Alpha.

Metode Statistika

Analisis Linear Regresi Berganda

Model regresi yang akan di gunakan dalam penelitian ini adalah 
$\mathrm{Y}=\mathrm{a}+\mathrm{b} 1 \mathrm{X} 1+\mathrm{b} 2 \mathrm{X} 2+\mathrm{b} 3 \mathrm{X} 3+\mathrm{b} 4 \mathrm{X} 4+\mathrm{b} 5 \mathrm{X} 5+\mathrm{e})$ dengan variabel $\mathrm{X} 1$ (sense marketing), X2 (feel marketing), X3 (act marketing), X4 (think marketing), X5 (relate marketing) dan variabel Y (Keputusan Pembelian).

Uji Secara Parsial (Uji - t)

Dasar pengambilan keputusan berdasarkan nilai signifikansi Ghozali (2006) adalah sebagai berikut :

a. Jika nilai signifikansi $\geq 0,05$, maka Ho tidak ditolak dan Ha ditolak.

Artinya tidak terdapat pengaruh yang signifikan dari variabel $\mathrm{X}$ terhadap variabel $\mathrm{Y}$.

b. Jika nilai signifikansi < 0,05, maka Ho ditolak dan Ha tidak ditolak.

Artinya, terdapat pengaruh yang signifikan dari variabel $\mathrm{X}$ terhadap variabel $\mathrm{Y}$.

Uji Secara Stimultan (Uji-F)

Menurut Endang (2011) Uji hipotesis secara stimultan yaitu suatu uji untuk mengetahui pengaruh variabel bebas secara simultan terhadap variabel terikat Untuk menentukan pengujian secara parsial maupun simultan, maka kriteria pengambilan keputusannya adalah sama dengan uji parsial

Hipotesis Penelitian

Menurut Sugiyono (2010) Hipotesis diartikan sebagai jawaban sementara terhadap rumusan masalah penelitian. Hipotesis dalam penelitian ini adalah:

$\mathrm{Ho}=$ Tidak terdapat pengaruh yang signifikan dari experiential marketing terhadap keputusan pembelian konsumen generasi millenial di platform ecommerce Blibli.comsecara parsial dan simultan

$\mathrm{Ha}=$ Terdapat pengaruh yang signifikan dari experiential marketing

terhadap keputusan pembelian konsumen generasi millenial di platform ecommerce Blibli.com secara parsial dan simultan

\section{HASIL PENELITIAN DAN PEMBAHASAN}

\section{Uji Validitas}

Tabel 1 Uji Validitas

\begin{tabular}{|l|r|l|l|}
\hline Variabel & r Hitung & r Tabel & Keterangan \\
\hline Sense 1 & .369 & 0.361 & Valid \\
\hline Sense 2 & .366 & 0.361 & Valid \\
\hline Sense 3 & .355 & 0.361 & Valid \\
\hline Sense 4 & .422 & 0.361 & Valid \\
\hline Feel 1 & .343 & 0.361 & Valid \\
\hline Feel 2 & .333 & 0.361 & Valid \\
\hline Feel 3 & .395 & 0.361 & Valid \\
\hline Think 1 & .383 & 0.361 & Valid \\
\hline Think 2 & .479 & 0.361 & Valid \\
\hline Think 3 & .495 & 0.361 & Valid \\
\hline
\end{tabular}

\begin{tabular}{|l|r|l|l|}
\hline Variabel & r Hitung & $\mathrm{r}$ Tabel & Keterangan \\
\hline Act 1 & .428 & 0.361 & Valid \\
\hline Act 2 & .451 & 0.361 & Valid \\
\hline Act 3 & .468 & 0.361 & Valid \\
\hline Relate 1 & .381 & 0.361 & Valid \\
\hline Relate 2 & .464 & 0.361 & Valid \\
\hline Relate 3 & .460 & 0.361 & Valid \\
\hline KK 1 & .459 & 0.361 & Valid \\
\hline KK 2 & .420 & 0.361 & Valid \\
\hline KK 3 & .441 & 0.361 & Valid \\
\hline KK 4 & .512 & 0.361 & Valid \\
\hline
\end{tabular}


National Conference of Creative Industry:

Sustainable Tourism Industry for Economic Development

Universitas Bunda Mulia, Jakarta, 5-6 September 2018

E- ISSN No: 2622-7436

\begin{tabular}{|l|l|l|l|} 
KK 5 & .462 & 0.361 & Valid \\
\hline
\end{tabular}

Sumber : Hasil pengolahan data, 2018

Dari tabel di atas dapat dilihat bahwa semua pernyataan yang dimiliki oleh seluruh variabel dinyatakan valid karena $r$ hitung yang bisa dilihat dari Correcred Item-Total Correlation dari pernyataan tersebut lebih besar $>$ dari $r$ tabel $(0,361)$.

\section{Uji Reliabilitas}

Tabel 2 Uji Reliabilitas

\begin{tabular}{|c|c|c|c|}
\hline Variabel & Cronbach's Alpha & $\begin{array}{c}\text { Cronbach's Alpha Based on } \\
\text { Standardized Items }\end{array}$ & N of Items \\
\hline Sense & 0.679 & 0.733 & 4 \\
\hline Feel & 0.654 & 0.664 & 3 \\
\hline Think & 0.604 & 0.621 & 3 \\
\hline Act & 0.684 & 0.695 & 3 \\
\hline Relate & 0.645 & 0.672 & 3 \\
\hline KK & 0.704 & 0.704 & 5 \\
\hline
\end{tabular}

Sumber : Hasil pengolahan data, 2018

Berdasarkan tabel diatas, seluruh nilai Cronbach's Alpha lebih besar $>$ dari 0,60 yang membuktikan jika seluruh pernyataan pada kuesioner adalah reliabel.

\section{Uji Analisis Regresi Linear}

Uji pengaruh dengan menggunakan uji t (secara parsial)

Tabel 3 Coefficients Uji t

\begin{tabular}{|c|c|c|c|c|c|c|}
\hline \multicolumn{7}{|c|}{ Coefficients $^{\mathrm{a}}$} \\
\hline \multirow{2}{*}{\multicolumn{2}{|c|}{ Model }} & \multicolumn{2}{|c|}{ Unstandardized Coefficients } & \multirow{2}{*}{$\begin{array}{c}\text { Standardized } \\
\text { Coefficients } \\
\text { Beta }\end{array}$} & \multirow[b]{2}{*}{$\mathrm{t}$} & \multirow[b]{2}{*}{ Sig. } \\
\hline & & B & Std. Error & & & \\
\hline \multirow[t]{6}{*}{1} & (Constant) & 1.067 & .491 & & 2.171 & .032 \\
\hline & Sense & -.002 & .122 & -.002 & -.017 & .987 \\
\hline & Feel & .301 & .095 & .314 & 3.157 & .002 \\
\hline & Think & .239 & .103 & .239 & 2.315 & .023 \\
\hline & Act & .345 & .107 & .046 & 3.224 & .034 \\
\hline & Relate & .160 & .084 & .196 & 1.894 & .061 \\
\hline
\end{tabular}

a. Dependent Variable: Keputusan

Sumber : Hasil pengolahan data, 2018 
Dari tabel di atas nilai signifikansi dari variabel feel,think, dan actadalah lebih kecil dari 0.05 sehingga masing-masing variabel memiliki pengaruh yang signifikan secara parsial terhadap terhadap keputusan pembelian konsumen generasi millenial di platform e-commerce Blibli.com. Sedangkan untuk variabel sense dan relatememiliki nilai signifikansi yang lebih besar dari 0.05 sehingga, variabel tersebut tidak memiliki pengaruh yang signifikan terhadap keputusan pembelian konsumen generasi millenial di platform e-commerce Blibli.com.

\section{Uji Pengaruh dengan Menggunakan Uji F (simultan)}

Tabel 4 Uji F

\begin{tabular}{|c|c|c|c|c|c|c|}
\hline \multicolumn{7}{|c|}{ ANOVA $^{b}$} \\
\hline & & Sum of Squares & df & Mean Square & $\mathrm{F}$ & Sig. \\
\hline \multirow[t]{3}{*}{1} & Regression & 9.483 & 5 & 1.897 & 7.214 & $.000^{\mathrm{a}}$ \\
\hline & Residual & 24.713 & 94 & .263 & & \\
\hline & Total & 34.196 & 99 & & & \\
\hline
\end{tabular}

a. Predictors: (Constant), Relate, Sense, Feel, Think, Act

b. Dependent Variable: Keputusan

Sumber : Hasil pengolahan data, 2018

Uji koefisien regresi variabel Independen terhadap variabel Dependen Ho : Variabel $\mathrm{X}_{1}$ (Sense), $\mathrm{X}_{2}$ (Feel), $\mathrm{X}_{3}$ (Act), $\mathrm{X}_{4}$ (Think) dan $\mathrm{X}_{5}$ (Relate) tidak berpengaruh secara signifikan terhadap variabel $\mathrm{Y}$ KK)

$\mathrm{Ha}$ : Paling sedikit ada 1 variabel Independent yang mempengaruh variabel Dependent.

Hasil :

Sig $=0,000<0,05$ maka Ho ditolak

\section{Kesimpulan :}

Berdasarkan tabel diatas didapat nilai probabilitas sebesar 0,000. Karena nilai probabilitas tersebut lebih kecil dari 0,05 , maka dapat dikatakan bahwa Experiential Marketing (Sense, Feel, Act, Think, Relate Marketing) secara stimultanpaling sedikit ada 1 variabel independent yang berpengaruh terhadap keputusan pembelian konsumen generasi millenial di platform e-commerce Blibli.com.

\section{KESIMPULAN DAN IMPLIKASI}

Berdasarkan dari hasil analisis maka diperoleh kesimpulan sebagai berikut:

1. Variabel X1 (Sense Marketing) tidak berpengaruh secara signifikan karena nilai signifikannya adalah $0,987>\alpha=0,05$ terhadap keputusan pembelian konsumen generasi millenial di platform e-commerce Blibli.com dengan tingkat keyakinan $95 \%$. 


\section{National Conference of Creative Industry: \\ Sustainable Tourism Industry for Economic Development}

Universitas Bunda Mulia, Jakarta, 5-6 September 2018

E- ISSN No: 2622-7436

2. Variabel X2 (Feel Marketing) berpengaruh secara signifikan karena nilai signifikannya adalah $0.002<\alpha=0,05$ terhadap keputusan pembelian konsumen generasi millenial di platform e-commerce Blibli.com dengan tingkat keyakinan 95\%.

3. Variabel X3 (Think Marketing) berpengaruh secara signifikan karena nilai signifikannya adalah $0.023<\alpha=0,05$ terhadap keputusan pembelian konsumen generasi millenial di platform e-commerce Blibli.com dengan tingkat keyakinan $95 \%$.

4. Variabel X4 (Act Marketing) berpengaruh secara signifikan karena nilai signifikannya adalah $0.034>\alpha=0,05$ terhadap keputusan pembelian konsumen generasi millenial di platform e-commerce Blibli.com dengan tingkat keyakinan 95\%.

5. Variabel X5 (Relate Marketing) tidak berpengaruh secara signifikan karena nilai signifikannya adalah $0.061>\alpha=0,05$ terhadap keputusan pembelian konsumen generasi millenial di platform e-commerce Blibli.com dengan tingkat keyakinan $95 \%$.

6. Variabel X1 (Sense Marketing), Variabel X2 (Feel Marketing), Variabel X3 (Think Marketing), Variabel X4 (Act Marketing) dan Variabel X5 (Relate Marketing) berpengaruh secara signifikan karena nilai signifikannya adalah $0,000<\alpha=0,05$, maka Ho ditolak sehingga dapat disimpulkan bahwa dari kelima variabel Experiential Marketing yang diteliti, paling sedikit ada satu variabel independen yang mempengaruhi variabel dependen dengan tingkat keyakinan $95 \%$

\section{Saran}

Dari hasil penelitian, analisis, dan simpulan, beberapa saran yang dapat peneliti sampaikan sebagai berikut :

1. Dari Variabel X1 (Sense Marketing) tidak berpengaruh signifikan terhadap keputusan pembelian konsumen generasi millenial di platform e-commerce Blibli.com. Hal ini dikarenakan indikator didalam sense marketing berhubugan langsung dengan panca indera dari manusia. Salah satu faktor kelemahan dalam berbelanja melalui platform e-commerce adalah tidak dapat di gunakannya indera manusia secara langsung. Penggunaan indera akan di gantikan oleh word of mouth dan review dari pelanggan lainnya. Generasi millenial yang sangat akrab dengan internet dan sosial media menggantungkan harapan dan dugaan untuk melakukan keputusan pembelian di platform e-commerce Oleh sebab itu, beberapa platform ecommerce memandang perlunya mendorong konsumen yang telah melakukan pembelian untuk memberikan review terhadap produk melalui pemberian point dari review tersebut.

2. Dari Variabel X2 (Feel Marketing) berpengaruh berpengaruh signifikan terhadap keputusan pembelian konsumen generasi millenial di platform e-commerce Blibli.com.

Dari teori yang dikemukakan pada tinjauan pustaka, feel dinyatakan sebagaiperasaan. Perasaan di sini sangatlah berbeda dengan kesan sensorik karena hal ini berkaitan dengan suasana hati dan emosi jiwa seseorang. Ini bukan sekedar menyangkut keindahan, tetapi suasana hati dan emosi jiwa yang mampu membangkitkan kebahagiaan atau bahkan kesedihan. Pada platform e-commerce saat ini seringkali menjalankan strategi unsur kejutan untuk konsumennya, contohnya pada Blibli.com 


\section{National Conference of Creative Industry: \\ Sustainable Tourism Industry for Economic Development}

Universitas Bunda Mulia, Jakarta, 5-6 September 2018

E- ISSN No: 2622-7436

adalah spektaflash yang hadir diwaktu-waktu tertentu dengan jumlah pembelian yang di batasi. Generasi millenial yang punya kecenderungan setiap saat terkoneksi dengan internet tentunya akan merasakansuasana hati yang baik karena telah 'memenangkan' spektaflash. Hal ini kemudian akan memunculkan keinginan untuk terus terkoneksi dengan platform e-commerce tersebut

3. Dari Variabel X3 (Think Marketing) berpengaruh berpengaruh signifikan terhadap keputusan pembelian konsumen generasi millenial di platform e-commerce Blibli.com. Dari teori dikatakan berpikir (think) dapat merangsang kemampuan intelektual dan kreativitas seseorang. Dalam penelitian ini, kreativitas dari platform $e$ commerce terlihat dari penawaran promosi yang tidak sekedar memberikan potongan harga, same day service dengan mengandalkan moda transportasi online yang memberikan kemudahan pengantaran barang dalam hari yang sama dengan pemesanan telah membuat generasi millenial semakin candu dalam kemudahan berbelanja secara online di platform tersebut.

4. Dari Variabel X4 (Act Marketing) berpengaruh signifikan terhadap keputusan pembelian konsumen generasi millenial di platform e-commerce Blibli.com.Variabel ini berhubungan dengan bagaimana membuat orang berbuat sesuatu dan mengekspresikan gaya hidupnya. Generasi millenial adalah generasi yang senang mengekspresikan gaya hidupnya melalui sosial media. Lagi-lagi hal ini dapat memicu keputusan pembelian yang dilakukan. Melalui platform sosial media, Blibli.com memanfaatkan sosial media untuk mempromosikan berbagai produk yang disediakan untuk menunjang gaya dan atau penampilan generasi millenial.

5 Dari Variabel X5 (Relate Marketing) tidak berpengaruh signifikan terhadap keputusan pembelian konsumen generasi millenial di platform e-commerce Blibli.com. Relate berkaitan dengan referensinya yang dapat menciptakan identitas sosial. Pada generasi millenial identitas sosial masih kerap berubah seiring dengan mudahnya dimasuki oleh pengaruh budaya asing yang ironisnya membuat generasi millenial terkadang tidak konsisten dalam keputusan pembeliannya

\section{DAFTAR PUSTAKA}

Andreani, Fransisca. 2007. Experiential Marketing (Sebuah Pendekatan Pemasaran). Jurnal Manajemen Pemasaran, Vol. 2 no. 1 April 2007.

Ardjuno Wiwoho. 2008. Pengetahuan Tata Hidang. Erlangga. Jakarta.

Arikunto, S. 2010. Prosedur penelitian : Suatu Pendekatan Praktik. (Edisi.Revisi). Rineka Cipta. Jakarta.

Endang Sulistya Rini. 2009. Menciptakan Pengalaman Konsumen dengan Experiential Marketing. Jurnal Manajemen Bisnis, Volume 2, Nomor 1, Januari 2009: 1 - 6

Gersom Hendarsono dan Sugiono Sugiharto. 2013. Analisa Pengaruh Experiential 


\section{National Conference of Creative Industry: \\ Sustainable Tourism Industry for Economic Development}

Universitas Bunda Mulia, Jakarta, 5-6 September 2018

E- ISSN No: 2622-7436

Marketing Terhadap Minat Beli Ulang Konsumen Cafe Buntos 99 Sidoarjo. Jurnal Manajemen Pemasaran Vol. 1, no. 2, 2013; 1-8

Ghozali, Imam, 2006. Aplikasi Analisis Multivarite dengan SPSS. Cetakan Keempat. Badan Penerbit Universitas Diponegoro. Semarang.

Ratih Hurriyati. 2008. Bauran Pemasaran Jasa dan Loyalitas Konsumen. Alfabeta. Bandung.

Schmitt, Bernd Schmitt. 1999. Experiential Marketing: How to Get Customers to Sense, Feel, Think, Act, Relate. The Free Press. Ney York

Smilansky, Shaz. 2009. Experiential Marketing: A Practical Guide to Interactive Brand Experiences. London and Philadelphia: Kogan Page.

Sugiyono. 2009. Metode Penelitian Kuantitatif, Kualitatif dan $R \& D$. Alfabeta. Bandung.

Uma Sekaran. 2006. Metodologi Penelitian untuk Bisnis Edisi 4 Buku 1. Salemba Empat. Jakarta. 